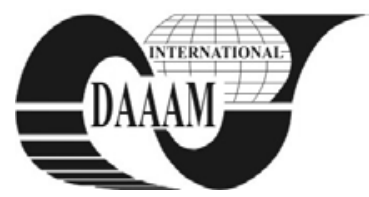

Annals of DAAAM for 2011 \& Proceedings of the 22nd International DAAAM Symposium, Volume 22, No. 1, ISSN 1726-9679 ISBN 978-3-901509-83-4, Editor B. Katalinic, Published by DAAAM International, Vienna, Austria, EU, 2011 Make Harmony between Technology and Nature, and Your Mind will Fly Free as a Bird Annals \& Proceedings of DAAAM International 2011

\title{
ENHANCING THE BUSINESS POTENTIAL OF FUNCTIONAL FOODS THROUGH TRADITIONAL GASTRONOMY
}

\author{
CHIRU, I[on] C[odrin] \& CHIRU, L[ina]
}

\begin{abstract}
Food companies have high expectations of the key role played by the functional foods in helping consumers to have a healthy lifestyle. This study explores experts' vision and knowledge and also consumers' acceptance of the health claims, attitudes and receptivity of a series of functional concepts that proved to have a high business potential in Romania. This paper concludes that food companies should drive consumption by designing functional foods close to traditional recipes in order to gain both emotional (familiarity and heritage) and functional (health reward, technological risk acceptance) character. Re-designing the traditional food by adding bio-active ingredients could become a key field in the agri-food business, able to build long term solutions to the actual agro-alimentary global challenges.
\end{abstract}

Key words: functional food, food design, Delphi

\section{INTRODUCTION}

In the last years, eating has become a complex sphere of life. Consumers have become more aware of the importance of food choices and much eager to adopt health-oriented habits regarding their food choices. The market success of functional foods is widely recognized to depend on consumer acceptance of the products as part of their daily diet. (Annunziata, A., Vecchio R., 2011) Although not yet (finally) defined by the EU legislation, functional foods have been characterized in various ways: 1) foods marketed as health enhancers, 2) aliments aimed at reducing the risk of disease or 3 ) a new variety of foods that promise specific improvement in physiological functions in the body (Diplock et al., 1999). Generally, the functional foods, through their particular bio-active components, are directly connected with well-defined physiological effects that drive noticeable health enhancements. Therefore, to become a commercial asset, this category needs scientifically proved substantiation of the related health effects. Building consumers trust is also a key component of this process. The industrial production of functional foods - that often requires modern food technology since a constituent needs to be added, removed or modified - increases the risk of this category to be perceived as less natural than conventional products, thus leading to avoidance behaviour and reluctance by those who value naturalness in food choices (Frewer, Scholderer, \& Lambert, 2003). These new trends have emerged into a new phenomenon, called „scientification” of eating. This concept is the outcome of the complex process that includes the mix of various scientific fields, such as: nutrition, dietology, medicine, pharmacology, bio-chemistry, gastronomy, food technology, marketing, business administration, etc.

Although taste is one of the most important choice factors when choosing functional foods, it was shown that the perceived health reward and the confidence in functional foods seem to be the most crucial factors in consumers' choice process. (Urala, N., Laahteenmaaki, L, 2004). Yet, the common consumer is hardly distinguishing between healthy food and functional food.

Studies made on users and non-users of specific types of functional foods concluded that consumers usually perceive functional foods and healthy eating from various perspectives such as: focus on daily diet, healthiness vs. functionality of foods, health vs. pleasure eating dilemma or the technological risk duality. (Niva, M., 2007) This diversity of perspectives reveals that connection between functional food and healthy eating has a considerable degree of uncertainty for the scientific knowledge.

\section{OBJECTIVES OF THE RESEARCH}

This study was undertaken to investigate experts' views on the new functional foods development in Romania and aims to prioritize those research areas that need development or improvement.

Innovation in functional food industry is a risky undertaking because of the recent bio-chemistry advancements that rapidly brought a large number of food improvements and technological variants. This study investigates which functional food concept could have the highest economic/business potential in order to successfully develop new marketable consumer products. Therefore this study, according to the participating experts' knowledge and experience, aimed at prioritizing and connecting three types of variables: different categories of food (source/base products), functional/bio-active compounds and the related health claims based on scientific proved biological activities/effects.

Another objective of this study was to test the consumers' acceptance of the proposed functional concepts, investigate their receptivity, health claim credibility, measure the attitude and determine the main drivers of the behavioural decision making.

\section{METHODOLOGY}

Considering the novelty and underdevelopment of the functional food industry in Romania, in order to investigate and align experts' views, it was implemented a three rounds Delphi survey - a consecrated explorative research tool, usually used to gain consensus among a heterogeneous experts panel in an emerging scientific domain. Most of the previous implementations proved that the Delphi method has advantages over common survey methods. Consequently, used correctly and rigorously, the Delphi approach can contribute significantly to broadening knowledge within the researched field (Keeneya, S. et al., 2001). The Delphi approach aims to minimize the variance between expert opinions based on traditional consensus (Steinert, M., 2009), therefore it was decided to conduct three rounds and, after each round, to allow individual adjustments based on the other experts' opinions and to obtain the mean value or equilibrium values of their votes.

Through the different stages of this technique it was followed an iterative process designed to combine expert opinion regarding foods, functional ingredients and health claims into a group consensus. The expert panel was formed by 23 professionals (all having more than 10 years experience in their field), from various fields linked to the food industry: nutritionists, food technologists, 
bio-chemistry engineers, marketers and academic researchers (food quality assessment and agro-industrial economics).

The investigation of the consumers' acceptance and receptivity of the functional concepts consisted in a questionnaire based survey among food shoppers in Bucharest, Romania. The final sample $(\mathrm{N}=104)$ included 69 females and 35 males, with an average age of 38,4 (S.D. $=10,2$ ). All the respondents had responsibility for food shopping in their households. The survey was focused on the evaluation of technological risk, health reward, familiarity with the selected functional concepts and willingness to try them.

\section{RESEARCH RESULTS \& DISCUSSION}

The first round of the Delphi survey started with open-ended questions, thus giving panel members freedom in their responses. The panellists were asked to indicate the general classes of bioactive compounds that could be used to develop or improve several types of functional foods, related to the market background and country specific mortality data. A few statements had intricate details and contained more than one variable. The average number of statements generated by each participant was five.

In the second round the panellists were asked to rate the previously identified classes of bioactive compounds (that were coded into variables) and re-arrange them in connection with their related biological effects and vegetal or animal sources (base products). The most frequently mentioned bio-active compounds were: Flavonoids (78\%), Carotenoids (65\%), Terpenoids (43\%), $\omega^{-3}$ fatty acids (39\%) and Coenzyme Q10 (35\%). Following the third round questionnaire, a Pearson's moment-product correlation coefficient (PPMCC) was measured to demonstrate the correlation of the mean scores of the statements among the groups within the panel. A significant positive correlation was found between the scores obtained from all the groups within the panel. The highest correlation coefficient was observed between the experts who proposed Flavonoids and Carotenoids, probably due to the similarities of experiences and characteristics among those two groups. The new functional food concepts that received the best scores are presented in the table below.

\begin{tabular}{|l|l|l|}
\hline \multicolumn{1}{|c|}{$\begin{array}{c}\text { Bio-active } \\
\text { compound }\end{array}$} & $\begin{array}{l}\text { Source/Base } \\
\text { product }\end{array}$ & Biological activity/effect \\
\hline Carotenoids & $\begin{array}{l}\text { Carrots, bell } \\
\text { peppers }\end{array}$ & $\begin{array}{l}\text { Antioxidant. Anti- } \\
\text { inflammatory, Anti- } \\
\text { carcinogenic }\end{array}$ \\
\hline $\begin{array}{l}\text { Terpenoids } \\
\text { (Terpineol, } \\
\text { Carvacrol, Thymol) }\end{array}$ & $\begin{array}{l}\text { Lovage, Sage, } \\
\text { Thyme }\end{array}$ & $\begin{array}{l}\text { Anti-septic, Anti- } \\
\text { inflammatory }\end{array}$ \\
\hline $\begin{array}{l}\text { Flavonoids: Flavones } \\
\text { (Apigenin, Luteolin), }\end{array}$ & $\begin{array}{l}\text { Onion, Garlic, } \\
\text { Celery, } \\
\text { Flavonols (Quercetin, } \\
\text { Kaempferol) }\end{array}$ & $\begin{array}{l}\text { Anti-inflammatory } \\
\text { Antioxidant } \\
\text { Anti-carcinogenic }\end{array}$ \\
\hline $\begin{array}{l}\text { Stilbenes } \\
\text { (Resveratrol) }\end{array}$ & Grapes & Anti-oxidant, Anti-aging \\
\hline $\begin{array}{l}\omega-3 \text { fatty acids, } \\
\text { Taurine }\end{array}$ & Fish & $\begin{array}{l}\text { Cholesterol-lowering } \\
\text { Cardiovascular and } \\
\text { Nervous system } \\
\text { regulators, } \\
\text { Anti-carcinogenic }\end{array}$ \\
\hline $\begin{array}{l}\text { Coenzyme Q10, } \\
\text { Creatine }\end{array}$ & $\begin{array}{l}\text { Meat (pork, } \\
\text { beef, lamb) }\end{array}$ & $\begin{array}{l}\text { Cardiovascular regulator } \\
\text { Anti-carcinogenic } \\
\text { Muscular enhancement }\end{array}$ \\
\hline Lactoferrin & Milk & $\begin{array}{l}\text { Anti-septic (antiviral, } \\
\text { antifungal, antibacterial) }\end{array}$ \\
\hline
\end{tabular}

Tab. 1. New concepts of functional foods

The results of the consumer survey demonstrated that, contrary to traditional specialities, functional foods are not associated with cultural values. The responses also show that consumers' attitudes and perception of the healthiness of functional foods are much more correlated with the perception of the bio-active qualities of the source/base product. Therefore, the producers should be aware in their marketing campaigns of this insight and aim at proposing health claims focused on the biological properties of the source/base products. The art of explaining complex scientific, technological processes and also health benefits to consumers in a very friendly and intuitive manner will be the key asset of the winners in this industry. Future research should be done on the propensity of consumers to buy functional foods and their willingness to adopt new nutrition patterns.

Many of the identified combinations (bio-active compound - source/base product - biological effect) have also been found in the Romanian traditional recipes (Stroia, A., Chiru, C., 2010), therefore food producers could use the traditional gastronomic repertoire as a platform to subsequently design new functional foods. Moreover, some important attitude and buying decision drivers (e.g. familiarity and heritage) could be assigned to the newly designed functional foods in order to strengthen their image and facilitate their market penetration.

\section{CONCLUSIONS}

This study reveals that the prioritized functional compounds (Flavonoids, Terpenoids, Carotenoids, $\omega-3$ fatty acidscoenzyme Q10) have a promising marketing perspective and their inclusion in consumers' daily diet could be a realistic task. Many functional compounds, corresponding to a series of prioritized base products (e.g. parsley, onion, garlic, celery, carrots, meat or fish) are frequently present in the traditional gastronomic recipes. Therefore the traditional gastronomic repertoire could be considered an inspirational base to further develop functional recipes not only by the Romanian food designers but also by the food producers across the world. From the marketing perspective, traditional specialties enhanced with bio-active ingredients could create the synergy from both functional and emotional benefits.

The functional reengineering of the traditional food could become an emerging domain in the agri-food business, capable to provide long term solutions to the actual global nutritional challenges.

\section{REFERENCES}

Annunziata, A., Vecchio R., (2011), Functional foods development in the European market: A consumer perspective, Journal of Functional Foods, Vol. 3, Issue 3, (July, 2011), pp. 223-228, ISSN: 1756-4646

Diplock, A. T., et al., (1999). Scientific concepts of functional foods in Europe: consensus document, British Journal of Nutrition, Vol. 81, No. 4, pp. 1-27 , ISSN:1475-2662

Frewer, L., Scholderer, J., \& Lambert, N. (2003). Consumer acceptance of functional foods: issues for the future. British Food Journal, Vol. 105, Iss: 10, pp. 714-731, ISSN: 0007-070X

Keeneya, S., et al., (2001) A critical review of the Delphi technique as a research methodology for nursing, International Journal of Nursing Studies, Vol. 2, No. 38, (April 2001), pp. 195-200, ISSN: 0020-7489

Niva, M., (2007), ‘All foods affect health': Understandings of functional foods and healthy eating among health-oriented Finns, Appetite, Vol. 48, Issue 3, (May, 2007), pp. 384393, ISSN: 0195-6663

Steinert, M., (2009) A dissensus based online Delphi approach: An explorative research tool, Technological Forecasting \& Social Change, Vol. 76, Iss: 3, (March 2009), pp. 291-300, ISSN: 0040-1625

Stroia, A., Chiru, C., (2010) Traditionalism and Functionality in the Romanian Cuisine, Quality-Access to Success, Year 11, Vol. 2, No. 116, (month and year of the edition), pp. 12341241, ISSN: 1582-2559

Urala, N., Laahteenmaaki, L, (2004), Attitudes behind consumers' willingness to use functional foods, Food Quality and Preference, Vol. 15, Iss: 7-8, (Oct-Dec 2004), pp. 793-803, ISSN: 0950-3293 